vol.6. No.1 - 2019

\title{
EFFECT OF USING GINGER TEA ON CHEMOTHERAPY- INDUCED NAUSEA AND VOMITING AMONG WOMEN WITH CANCER
}

\author{
Hala Ahmad Thabet ${ }^{1}$ Amany Mohammed Safwat ${ }^{2}$ Mona Afify ${ }^{3}$ \\ ${ }^{1}$ Faculty of Nursing, Woman's Health and Midwifery Nursing Department, Mansoura University, Egypt. \\ ${ }^{2}$ Faculty of Nursing Medical Surgical Department Nursing Department, Ain Shams University, Egypt \\ ${ }^{3}$ Faculty of Medicine, Medical Microbiology\& Immunology Department, Zagazing University, Egypt \\ Corresponding author: hala_thabet67@hotmail.com
}

\begin{abstract}
Background: Chemotherapy-induced nausea and vomiting (CINV) remains a significant reason of distress and dissatisfaction among patients getting cancer treatment. Aim: The aim of this study is to assess the effect of ginger tea on chemotherapy induced nausea and vomiting in women with cancer. Study Design: A quasi-experimental research design. Sampling: A purposive sample of 100 women with gynecological and breast cancer. Setting: This study was conducted at the outpatient clinics of oncology and nuclear medicine department affiliated to Ain Shams University Hospital. Tools: Three tools were used for the data collection of this study I. A Patient interview questionnaire included patients' demographic and clinical data, II. Simplified form of Rhodes index of nausea, vomiting and retching assessment scale. III. Patients _satisfaction questionnaire Results: The mean age of all patients was $5.84+36.79$ years, $17(34 \%)$ of the patients in the control group had secondary educational level, while 19 (38\%) in experimental group were university graduates. $35(70 \%)$ and $36(72 \%)$ of patients in the control group and experimental group were married. $(54 \%, 60 \%)$ of patients in the control group and experimental group were employed. Regarding total vomiting and nausea experience score, there was no significant difference between both groups before research intervention and during the first $6,12 \& 24$ hours after chemotherapy. However, there was a statistically significant association in intervention (ginger tea group) and control group on the second day, third day and fourth day post chemotherapy $(\mathrm{p}=<0.001)$. Conclusions and recommendations: The current study showed that ginger tea can be administered to patients with gynecologic and breast cancer as a safe herbal medicine for effective prevention of chemotherapy-induced nausea and vomiting. Prospective studies and longer periods of follow up are also helpful to assess the efficacy of ginger supplementation on the prevalence of CINV symptoms in patients receiving multiple cycles of chemotherapy.

Keywords: ginger tea, chemotherapy-induced nausea and vomiting (CINV), gynaecologic and breast cancer
\end{abstract}

\section{Introduction:}

Chemotherapy-induced nausea and vomiting (CINV) is a significant burden for patients undergoing chemotherapy. Nausea and vomiting are rated as two of the most distressing symptoms by chemotherapy patients and have been shown to significantly and adversely affect quality of life and physical function during treatment. (Sun et al.,2005). Chemotherapy-induced nausea and

vomiting (CINV) remains a significant reason of distress and dissatisfaction among clients getting cancer treatment. There are two different forms of CINV: acute ( $\leq 24 \mathrm{~h}$ after chemotherapy) and delayed ( $>24 \mathrm{~h}$ after chemotherapy). (Kottschade et al, 2016).

During chemotherapy, cell injury caused within the gastrointestinal tract (GIT) results in the release of multiple 
Hala Ahmad Thabet et., al.

inflammatory factors including cyclooxygenase-2 (COX-2), interleukin- 6 (IL6), and nuclear factor kappa-B (NF$\mathrm{kB})$. The end result of this pathway is continued tissue damage and potentially mucositis along the length of the GIT. (Sultani et al., 2012) It has been suggested that inflammation and cell injury may be particularly involved in the delayed phase of CINV. (Hesketh, 2008). Ginger compounds have also demonstrated an anti-inflammatory effect in murine and rat models, with these effects replicated in human clinical trials. (Ojewole, 2006; Zick et al., 2011)

Ginger is used in numerous forms, including fresh, dried, pickled, preserved, crystallized, candied, and powdered or ground. Presentations can include capsules, tablets, tinctures, teas, and liquid extracts. (Baliga et al, 2011)

In relation to its antiemetic properties of ginger and its components acts peripherally, within the gastrointestinal tract, by increasing the gastric tone and motility due to anti-cholinenergic and anti-serotonergic actions. It is also stated to rise gastric emptying. This mixture of functions clarifies the extensively accepted ability of ginger to release symptoms of functional gastrointestinal complaints, such as dyspepsia, abdominal pain, and nausea, which are often associated with reduced gastric motility. (Lete \& Allué 2016)

Nowadays, cancer therapy consists of surgery, radiotherapy, chemotherapy and biological therapy as well as some other methods, whereas in the locally advanced stage, chemotherapy such as Trastuzumab therapy is often the only effective method of cancer therapy (Payandeh et al., 2015). Cancers affecting any part of the female reproductive system e.g., in the vulva, vagina, cervix, uterus, fallopian tubes, or ovaries and breast can directly invade nearby tissues and organs or spread through the lymphatic vessels and lymph nodes or bloodstream to distant parts of the body (David et al., 2017).

Nausea and vomiting are common and feared symptoms among cancer women (Teunissen,et al 2007). Of the 70 to $80 \%$ of cancer patients who experience chemotherapy-induced nausea and vomiting several will delay or reject future chemotherapy treatments and expect stopping all treatments because of fear of further nausea and vomiting. (Mustian KM, Darling TV, Morrow GR 2008). The likelihood that nausea and vomiting will develop after chemotherapy treatment depends on several factors, with female patients and younger patients being at greater risk (Hesketh 2008).

Significant of the study:

Health care practitioners, especially nurses have the role, duty, and ability to assess, diagnose, control, cure, and prevent the emesis as the most common chemotherapy-induced complication. Therefore, nurses can use CAT, especially herbal medicine as an effective and applicable method to relieve CIV and increase cancer patients welfare and comfort. (Black, Hawks, 2009).So, this study was only performed on the women with gynecological and breast cancer as the most prevalent cancer among women, because any type of cancer has its own particular chemotherapy protocol with different emetogenicity (Dundar et al ,2006 ; Edwards , Palomares, 2008). In the present study, the researchers provide appropriate intervention of using the antiemetic (ginger tea) to assess its effect of on chemotherapy induced nausea and vomiting in women with cancer.

Aim of the study:

The present study aimed to assess the effect of ginger tea on chemotherapy induced nausea and vomiting in women with cancer. This aim was achieved through the followings:

1. Assessing the occurrence of nausea and vomiting by using a simplified 
form of Rhodes index before and post chemotherapy session.

2. Assessing the severity and the distress of nausea and vomiting by using a simplified form of Rhodes index before and post chemotherapy session.

3. Assessing woman's' satisfaction towards the administration of ginger tea to relieve chemotherapy induced nausea and vomiting.

Research hypothesis:

In order to achieve the aim of this study, it was hypothesized that:

There was a positive effect of ginger tea upon intervention group (ginger group) more than control group in controlling nausea and vomiting before and post chemotherapy session among women with cancer.

\section{Subjects And Methods}

Study design:

A quasi-experimental research design was utilized in the current study.

Setting:

The study was carried out at the outpatient clinics of oncology and nuclear medicine department affiliated to Ain Shams University Hospital.

\section{Subjects:}

A non-probability purposive sample of 100 patients with gynecological (i.e., the vulvar, vagina, cervix, endometrium, fallopian tube, ovaries) and breast cancer. Inclusion criteria: women ages were between 20 and 60 years; history of receiving at least one chemotherapy injection, receiving single-day cycles of chemotherapy (each cycle separated from next by $\geq 2$ weeks); experiencing vomiting in previous sessions, and having normal values of hematologic and biomedical laboratory parameters. Exclusion criteria: women undergoing more than 1 cycle of chemotherapy; who currently receiving radiotherapy; taking therapeutic doses of warfarin, aspirin, or heparin; had a history of bleeding disorder(s) like severe thrombocytopenia; Clients with metastasis, had an allergy to ginger or chamomile or had taken it in the last week; had gastrointestinal disorders or malignancies; had other emesis-inducing diseases, such as hypertension, liver, and renal failure, cardiovascular disorders and any factor affecting clotting time, and the women's who forgotten to take $500 \mathrm{mg}$ of fresh ginger $\geq 3$ consecutive times; used other antiemetic drugs or therapeutic methods except the routine antiemetic; had severe gastrointestinal problems during the study; did not have a telephone line and illiterate .

Tools for data collection:

The study data was collected using the following three tools:

I. Patient interview questionnaire; This questionnaire was developed by the researcher based on review of relevant as well as current and updated literature and practice guidelines. The patient interview questionnaire included two main parts: in Arabic:

- Part one. Patients' characteristics: this part was developed to assess patients ${ }^{6}$ demographic data, including: Patients' age, level of education, marital status and occupation).

- Part two. Patients' clinical data: It is used to assess patients' medical data such as, (types, and grads of cancer)

II. Rhodes Index of Nausea, Vomiting and Retching assessment scale:

Nausea is a non-observable phenomenon, while vomiting is objective, and the occurrence and the frequency of vomiting may be measured. are used to assess nausea and vomiting based on selfreporting. The Rhodes index of nausea, vomiting and retching assessment scale was a simplified form to assess the frequency occurrence, severity, distress associated with of vomiting and the approximate volume of the vomitus. It was adopted from (Fetzer et al, 2004), The Rhodes index scale is 8-item, a 5point Likert scale ranging from 0 to 4 , 
with larger scores indicating more symptoms. This form involves eight items that ranging from mild (zero) to very severe (four) with a maximum total score of 32.The score being zero in -nonell classification. For example, if the maximum possible score was 32 , then, none: 0, mild: 1-8, moderate: 9-16,

severe: 17-24, great: 25-32. Nausea and the number of vomiting and retching episodes were evaluated four times each day for four days by the woman beginning on in the first 6 hours of day 1 (the day of chemotherapy infusion) in the woman diary, between 6 to 24 hours, and days 2, 3, and 4 after chemotherapy. Follow-up telephone interviews were conducted by the researchers on days 2,3 and 4 post-chemotherapies.

\section{Patients' questionnaire: \\ satisfaction}

It was designed by the researchers to assess participant women's satisfaction toward the administration of ginger tea.

\section{Content validity:}

The tools were reviewed by a panel of five experts from Maternity \& Reproductive Health Nursing, Medical Surgical Nursing of faculty and Medical Oncology (two experts in each field) to face and content validity of the study tool. Results of their evaluation were fully considered regarding the tools' format, layout, consistency and scoring system.

\section{Research}

Administrative design:

The necessary official approvals were obtained from the administrators at the outpatient clinics of oncology and nuclear medicine department affiliated to Ain Shams University Hospital. Letters of request were issued to them from the Faculty of Nursing at Ain Shams University explaining aim of the study and its expected outcomes.

\section{Ethical Issues:}

Before the initial interview, an oral consent was secured from each subject after being informed about the nature, purpose and benefits of the study. Women were also informed that participation is voluntary and about their right to withdraw at any time without giving reasons. Confidentiality of any obtained information was ensuring through coding of all data. The researchers reassured patients that the data would be used only for the research purpose.

\section{Pilot study:}

A pilot study was carried out on $10 \%$ of the total study sample (10 women) to test the study process ' clarity, feasibility and practicability of the tools in addition to the subjects and settings .Pilot subjects' data were later included in the study as there was no major modifications in the study tools .The reliability of the developed tool was tested using Cronbach's alpha coefficient with a reliability coefficient of 0.89 .

\section{Fieldwork:}

O The study was implemented during the period from May 2015 to January 2016.

O The study tools were designed by the researchers after reviewing the relevant literatures.

O Content validity and reliability tests were done before starting data collection process.

\section{Nursing intervention guidelines:} Assessment phase:

To carry out the study, the necessary approval was obtained from the director of the outpatient clinic of affiliated to AinShams university hospital, the researchers interviewed women who meet the eligibility criteria were enrolled either to the study or the control groups, each participant women interviewed individually, from 10-15 minutes and explained the aim of the study and the procedures were explained briefly and clearly for each participant women with cancer to obtain their cooperation and acceptance for data collection and the 
EFFECT OF USING GINGER TEA ON CHEMOTHERAPY-INDUCED etc...

assurance of confidentiality of their responses was confirmed.

\section{Planning phases:}

Participants were randomized sequentially into two equal study groups (i.e. intervention and control groups), each group consisted of 50 women. The necessary amount of ginger tea for the whole course was provided by the researchers to all participants in the intervention group.

Implementation and evaluation phase: Ginger tea was prepared by adding 500 $\mathrm{mg}$ of fresh ginger roots to $200 \mathrm{ml}$ of boiled water and simmered for 10-20 minutes and add a little honey for taste, to be administered orally to the woman in a dose of three cups daily every 8 hours, on intervals for 6 days starting 2 days before the chemotherapy session and 4 days after chemotherapy at home accompanied by the routine hospital care for both groups ,the routine antiemetic regimen, including (i.e., granisetron and dexamethasone ampoules $8 \mathrm{mg} /$ day). After that, the researchers recorded how many times of both (ginger \& control) groups felt nauseated, vomited, or retched (dry heaved), as well as how severe each episode was, at specific time periods after chemotherapy -in the first 6 hours, between 12 and 24 hours, day two, three $\&$ four after chemotherapy by using a simplified form of Rhodes index of nausea, vomiting and retching assessment scale to compare the effectiveness of ginger tea administration between intervention and control group. Every woman received 12 copies of the Rhodes Index form (in Arabic). They also received instructions to complete the form every 8 hours and to record the intensity of the signs (nausea, vomiting, and retching). Each woman was followed by telephone calls conducted by the researchers on days 2, 3 and 4 after chemotherapy and in cases of intolerable complications stops the consumption and contacts the researchers for more information.

\section{Statistical Analysis:}

Data were presented using number and percentage, means and standard deviations. Chi-square test was applied to compare differences in experienced symptoms among patients in both groups. P- Values less than 0.05 were considered as statistically significant.

\section{Results}

Table (1) illustrated that $20(40 \%)$ of the participants in the control group were in the age group 35-49 and $26(52 \%)$ of the participants in the experimental group were in the age group $\geq 50$ years. Regarding participants “ educational level about one third $17(34 \%)$ of the participants in the control group had secondary level, while more than one third 19(38) in experimental group were university graduates. $35(70 \%)$ and $36(72 \%)$ of participants in the control group and experimental group were married. More than one half $(54 \%, 60 \%)$ of participants in the control group and experimental group were employed.

Table (2) Showed that nearly one third $(32 \%)$ of participants in the control group and two fifth (40\%) of the participants in experimental group had breast cancer, followed by more than one quarter $(26 \%$, $28)$ of participant in control and experimental group had cervical cancer. while. the rest of them had vulvar and vaginal cancer (4\% and $2 \%$ ) respectively in both groups. Regarding grads of cancer two fifths $(40 \%)$ of participants in experimental group had grad one, followed by grade II1 and grade II $(30 \%$, $24 \%$ ) respectively . while more than one third $(36 \%)$ of participant in the control group had grade 1 followed by grade 11 and $111(26 \%, 26 \%)$ respectively.

Table (3) shows that, regarding Rhodes index score of nausea \& vomiting experience at baseline and during intervention in both groups (study and 
control group), there was no significant difference between study groups and control group before intervention and during the first $6,12 \& 24$ hours after chemotherapy. However, there was a statistically significant deference in intervention group (ginger tea) and control group on the second, third and fourth day post chemotherapy $(p=<0.001)$.

Table (4) showed that, regarding total vomiting and nausea occurrence score , there was no significant difference between study groups and control group before research intervention and during the first $6,12 \& 24$ hours after chemotherapy. There was a statistically significant association in intervention (ginger tea group) and control group on the second day, third day and fourth day post chemotherapy ( $p=<0.001$ )

Table (5) illustrated that, regarding total vomiting and nausea distress score, there was no significant difference between study groups and control group before research intervention and during the first $6,12 \& 24$ hours after chemotherapy. However, there was a statistically significant association in intervention (ginger tea group) and control group on the second day, third day and fourth day post chemotherapy $(p=<0.001)$

Table (6) shows that, regarding severity of experienced nausea, there was no significant difference between study groups and control group during the first $6,12 \& 24$ hours after chemotherapy. However, afterwards, significantly less patients in the intervention experienced moderate or severe nausea on the second day $(\mathrm{p}=0.043)$, on the third day $(\mathrm{p}=0.019)$ and on the fourth day ( $\mathrm{p}=0.044$ )

Table (7) shows that $80 \%$ of participants in the intervention group were satisfied with ginger tea intake to control their nausea after receiving chemotherapy and a similar percentage $80 \%$ stated that they preferred future use

Table (1): Distribution of women" socio-demographic characteristics $(\mathrm{N}=100)$

\begin{tabular}{|c|c|c|c|c|}
\hline & \multicolumn{4}{|c|}{ Studied sample } \\
\hline & \multicolumn{2}{|c|}{ Ginger tea group } & \multicolumn{2}{|c|}{ Contr 1 group $n=50$} \\
\hline & No & $\%$ & No & $\%$ \\
\hline \multicolumn{5}{|l|}{ Age (in years) } \\
\hline $0<35$ & 11 & $22 \%$ & 13 & $\begin{array}{l}26 \\
\%\end{array}$ \\
\hline $\begin{array}{ll}\text { o } & 35-49\end{array}$ & 13 & $26 \%$ & 20 & $\begin{array}{l}40 \\
\%\end{array}$ \\
\hline $0 \geq 50$ & 26 & $52 \%$ & 17 & $\begin{array}{l}34 \\
\%\end{array}$ \\
\hline \multicolumn{5}{|c|}{$\begin{array}{c}\text { Mean }+ \text { SD } \\
\mathbf{5 . 8 4 + 3 6 . 7 9 y} \\
\text { eas }\end{array}$} \\
\hline \multicolumn{5}{|l|}{ Educational level } \\
\hline o $\quad$ Read and write & 13 & $26 \%$ & 12 & $\begin{array}{l}24 \\
\%\end{array}$ \\
\hline o $\quad$ Basic education & 7 & $14 \%$ & 11 & $\begin{array}{l}22 \\
\%\end{array}$ \\
\hline $\begin{array}{ll}\text { o } & \text { Secondary }\end{array}$ & 11 & $22 \%$ & 17 & $\begin{array}{l}34 \\
\%\end{array}$ \\
\hline o $\quad$ University & 19 & $38 \%$ & 10 & $\begin{array}{l}20 \\
\%\end{array}$ \\
\hline
\end{tabular}


EFFECT OF USING GINGER TEA ON CHEMOTHERAPY-INDUCED etc...

\begin{tabular}{|l|c|c|c|c|}
\hline \hline Marital status & $16 \%$ & 10 & $\begin{array}{c}20 \\
\%\end{array}$ \\
\hline o Single & 8 & $72 \%$ & 35 & $\begin{array}{c}70 \\
\%\end{array}$ \\
\hline o Married & 36 & $8 \%$ & 2 & 4 \\
$\%$ \\
\hline o Separated/divorced
\end{tabular}

Table (2): Frequency distribution of clinical data for women with cancers $(\mathrm{N}=100)$

\begin{tabular}{|c|c|c|c|c|}
\hline \multirow[t]{3}{*}{ Clinical data } & \multicolumn{4}{|c|}{ Studied sample } \\
\hline & \multicolumn{2}{|c|}{ Ginger tea group $n=50$} & \multicolumn{2}{|c|}{ Control group $\mathrm{n}=50$} \\
\hline & $\begin{array}{r}\text { No } \\
\end{array}$ & $\%$ & No & $\%$ \\
\hline \multicolumn{5}{|l|}{ Types of cancer } \\
\hline o Endometrial cancer & 9 & $18 \%$ & 10 & $20 \%$ \\
\hline o Ovarian cancer & 5 & $10 \%$ & 7 & $14 \%$ \\
\hline o Cervical cancer & 14 & $28 \%$ & 13 & $26 \%$ \\
\hline o Vulvar cancer & 1 & $2 \%$ & 2 & $4 \%$ \\
\hline o Vaginal cancer & 1 & $2 \%$ & 2 & $4 \%$ \\
\hline o Breast cancer & 20 & $40 \%$ & 16 & $32 \%$ \\
\hline \multicolumn{5}{|l|}{ Grads of cancer } \\
\hline $\begin{array}{ll}\mathrm{O} & 0\end{array}$ & 3 & $6 \%$ & 6 & $12 \%$ \\
\hline o & 20 & $40 \%$ & 18 & $36 \%$ \\
\hline \begin{tabular}{|l|l|}
0 & 11 \\
\end{tabular} & 12 & $24 \%$ & 13 & $26 \%$ \\
\hline $\begin{array}{|ll|}0 & 111 \\
\end{array}$ & 15 & $30 \%$ & 13 & $26 \%$ \\
\hline
\end{tabular}

Table (3): Rhodes index score of nausea \& vomiting experience at baseline and during treatment with both groups for intervention group and control group no $=50$

\begin{tabular}{|c|c|c|c|c|c|c|c|c|}
\hline \multirow[t]{2}{*}{$\begin{array}{l}\text { Day of } \\
\text { assessment }\end{array}$} & \multicolumn{3}{|c|}{$\begin{array}{l}\text { Nausea \& Vomiting experience scores in } \\
\text { Ginger tea group } \quad n=50\end{array}$} & \multicolumn{3}{|c|}{$\begin{array}{c}\text { Nausea \& Vomiting experience scores } \\
\text { in Control group } n=50\end{array}$} & \multirow[t]{2}{*}{ t Val } & \multirow[t]{2}{*}{ p-value } \\
\hline & $\begin{array}{c}\text { Minimum } \\
\text { Score }\end{array}$ & $\begin{array}{c}\text { Maximum } \\
\text { Score }\end{array}$ & Mean \pm SD & $\begin{array}{c}\text { Minimum } \\
\text { Score }\end{array}$ & $\begin{array}{l}\text { Maximu } \\
\text { m Score }\end{array}$ & Mean \pm SD & & \\
\hline $\begin{array}{l}\text { Baseline } \\
\text { (Before } \\
\text { research } \\
\text { interventio) }\end{array}$ & 11 & 28 & $9.98 \pm 2.45$ & 14 & 30 & $20.45 \pm 2.74$ & 0.904 & 0.368 \\
\hline 6 hours & 9 & 22 & $14.8 \pm 4.54$ & 12 & 24 & $16.03 \pm 3.62$ & 1.498 & 0.137 \\
\hline \begin{tabular}{|l|l}
$12-24$ \\
hours
\end{tabular} & 6 & 20 & $12.87 \pm \mathbf{3 . 1}$ & 9 & 20 & $14.2 \pm 4.23$ & 1.793 & 0.076 \\
\hline Day 2 & 4 & 16 & $10.23 \pm 3.56$ & 7 & 17 & $11.78 \pm 3.59$ & 2.168 & $* 0.032$ \\
\hline Day 3 & & 12 & $5.98 \pm 2.45$ & 6 & 14 & $9.45 \pm 2.87$ & 6.502 & $<0.001 * *$ \\
\hline Day 4 & 2 & 12 & $5.77 \pm 2.14$ & 4 & 10 & $6.83 \pm 2.5$ & 2.278 & $0.025^{*}$ \\
\hline
\end{tabular}

*Total experience score: sum of all scores items $(1-8$ items $)=32$ 
Hala Ahmad Thabet et., al.

\begin{tabular}{|c|c|c|c|c|c|c|c|c|}
\hline \multirow[t]{2}{*}{$\begin{array}{l}\text { Day of } \\
\text { assessment }\end{array}$} & \multicolumn{3}{|c|}{$\begin{array}{c}\text { Nausea \& Vomiting occurrence } \\
\text { scores in } \\
\text { Ginger tea group } n=50\end{array}$} & \multicolumn{3}{|c|}{$\begin{array}{c}\text { Vomiting \& Nausea Occurrence } \\
\text { scores in } \\
\text { Control group } n=50\end{array}$} & \multirow[t]{2}{*}{ t Value } & \multirow[t]{2}{*}{ p-value } \\
\hline & \begin{tabular}{|l} 
Minimun \\
Score
\end{tabular} & $\begin{array}{l}\text { Maximu } \\
\text { m Score }\end{array}$ & Mean \pm SD & $\begin{array}{l}\text { Minimum } \\
\text { Score }\end{array}$ & \begin{tabular}{|l|}
$\begin{array}{l}\text { Maximum } \\
\text { Score }\end{array}$ \\
\end{tabular} & Mean \pm SD & & \\
\hline $\begin{array}{l}\text { Baseline (Before } \\
\text { research } \\
\text { intervention) }\end{array}$ & 8 & 17 & $11.76 \pm 3.64$ & 11 & 19 & $12.57 \pm \mathbf{3 . 2 1}$ & 1.180 & 0.241 \\
\hline 6 hours & 6 & 14 & $9.96 \pm 3.12$ & 9 & 17 & $11.1 \pm 3.24$ & 1.792 & 0.076 \\
\hline \begin{tabular}{|l|}
$12-24$ \\
hours
\end{tabular} & 4 & 11 & $8.84 \pm 2.85$ & 8 & 15 & $10.05 \pm 3.47$ & 1.905 & 0.060 \\
\hline Day 2 & 3 & 5 & $3.96 \pm 0.84$ & 7 & 13 & $9.66 \pm 2.15$ & 17.461 & $<0.001 * *$ \\
\hline Day 3 & 1 & 3 & $1.78 \pm 0.57$ & 5 & 11 & $8.4 \pm 2.31$ & 19.674 & $<0.001$ *** \\
\hline Day 4 & 0 & 2 & $1.1 \pm 0.45$ & 3 & 9 & $5.23 \pm 2.56$ & 11.235 & $<0.001 * *$ \\
\hline
\end{tabular}

* Total occurrence score $=(20)$; items No. $(1,4,6,7 \& 8)$

Table (5): Rhodes index score of nausea \& vomiting distress at baseline and during treatment with both groups for intervention group and control group no=100

\begin{tabular}{|c|c|c|c|c|c|c|c|c|}
\hline \multirow[t]{2}{*}{ Day of assessment } & \multicolumn{3}{|c|}{$\begin{array}{l}\text { a \& Vomiting distress scores in } \\
\text { Ginger tea group }(n=50)\end{array}$} & \multicolumn{3}{|c|}{$\begin{array}{l}\text { Nausea \& Vomiting distress } \\
\text { scores Control group }(n=50)\end{array}$} & \multirow[t]{2}{*}{ t Value } & \multirow[t]{2}{*}{ p-value } \\
\hline & $\begin{array}{c}\text { Minimum } \\
\text { Score }\end{array}$ & $\begin{array}{c}\text { Maximum } \\
\text { Score }\end{array}$ & $\begin{array}{l}\text { Mean } \pm \\
\text { SD }\end{array}$ & $\begin{array}{l}\text { Minimum } \\
\text { Score }\end{array}$ & $\begin{array}{l}\text { Maximum } \\
\text { Score }\end{array}$ & Mean \pm SD & & \\
\hline $\begin{array}{l}\text { - Baseline (Before } \\
\text { research } \\
\text { intervention) }\end{array}$ & 7 & 12 & $9.17 \pm 1.87$ & 6 & 12 & $8.52 \pm 1.86$ & 1.743 & 0.085 \\
\hline-6 hours & 4 & 8 & $5.85 \pm 1.32$ & 6 & 10 & $6.23 \pm 1.45$ & 1.370 & 0.173 \\
\hline 12-24 hours & 3 & 6 & $6.51 \pm 1.1$ & 5 & 10 & $7.07 \pm 2.31$ & 1.548 & 0.125 \\
\hline Day 2 & 2 & 3 & $2.35 \pm 0.29$ & 4 & 9 & $6.25 \pm 1.13$ & 23.639 & $<0.001 * *$ \\
\hline Day 3 & 1 & 4 & $2.45 \pm 1.03$ & 3 & 8 & $5.84 \pm 1.2$ & 15.158 & $<0.001 * *$ \\
\hline Day 4 & 1 & 2 & $1.12 \pm 0.7$ & 2 & 6 & $3.75 \pm 1.65$ & 10.376 & $<0.001 * *$ \\
\hline
\end{tabular}

* Total distress score $=(12)$; items no. $(2,3 \& 5)$.

Table (6): Comparing Nausea Severity (based on the Rhodes Index (distress) between study groups on different days after chemotherapy

\begin{tabular}{|c|c|c|c|c|c|c|c|}
\hline \multirow[t]{2}{*}{ Period } & \multirow[t]{2}{*}{$\begin{array}{l}\text { Severity of } \\
\text { Symptoms }\end{array}$} & \multicolumn{2}{|c|}{$\begin{array}{c}\text { Intervention Group } \\
\qquad(\mathrm{n}=50)\end{array}$} & \multicolumn{2}{|c|}{$\begin{array}{c}\text { Control Group } \\
(\mathbf{n}=50)\end{array}$} & \multirow[t]{2}{*}{$\square^{2}$} & \multirow[t]{2}{*}{$\begin{array}{c}\mathbf{P} \\
\text { Value }\end{array}$} \\
\hline & & No. & $\%$ & No. & $\%$ & & \\
\hline \multirow[t]{5}{*}{6 hours } & No & 44 & 88 & 39 & 78 & \multirow[t]{5}{*}{1.968} & \multirow[t]{5}{*}{0.579} \\
\hline & Mild & 3 & 6 & 6 & 12 & & \\
\hline & Moderate & 2 & 4 & 4 & 8 & & \\
\hline & Great & 1 & 2 & 1 & 2 & & \\
\hline & Severe & 0 & 0.0 & 0 & 0.0 & & \\
\hline \multirow[t]{5}{*}{ 12-24 hours } & No & 43 & 86 & 32 & 64 & \multirow{5}{*}{6.947} & \multirow{5}{*}{0.139} \\
\hline & Mild & 4 & 8 & 8 & 16 & & \\
\hline & Moderate & 1 & 2 & 5 & 10 & & \\
\hline & Great & 1 & 2 & 2 & 4 & & \\
\hline & Severe & 1 & 2 & 3 & 6 & & \\
\hline \multirow[t]{3}{*}{$2^{\text {nd }}$ day } & No & 37 & 74 & 22 & 44 & \multirow{3}{*}{9.869} & \multirow{3}{*}{$0.043 *$} \\
\hline & Mild & 7 & 14 & 12 & 24 & & \\
\hline & Moderate & 3 & 6 & 8 & 16 & & \\
\hline
\end{tabular}


EFFECT OF USING GINGER TEA ON CHEMOTHERAPY-INDUCED etc...

\begin{tabular}{|c|c|c|c|c|c|c|c|}
\hline & Great & 2 & 4 & 4 & 8 & & \\
\hline & Severe & 1 & 2 & 4 & 8 & & \\
\hline \multirow{5}{*}{$3^{\text {rd }}$ day } & No & 39 & 78 & 29 & 58 & \multirow{5}{*}{11.763} & \multirow{5}{*}{$0.019 *$} \\
\hline & Mild & 8 & 16 & 5 & 10 & & \\
\hline & Moderate & 2 & 4 & 8 & 16 & & \\
\hline & Great & 1 & 2 & 3 & 6 & & \\
\hline & Severe & 0 & 0.0 & 5 & 10 & & \\
\hline \multirow[t]{5}{*}{$4^{\text {th }}$ day } & No & 41 & 82 & 33 & 66 & \multirow{5}{*}{9.817} & \multirow{5}{*}{$0.044^{*}$} \\
\hline & Mild & 8 & 16 & 6 & 12 & & \\
\hline & Moderate & 1 & 2 & 5 & 10 & & \\
\hline & Great & 0 & 0.0 & 2 & 4 & & \\
\hline & Severe & 0 & 0.0 & 4 & 8 & & \\
\hline
\end{tabular}

(*) Statistically significant at $\mathrm{p}<0.05$

Table (7): Distribution of women satisfaction towards ginger tea administration $(n=50)$

\begin{tabular}{|l|c|c|}
\hline Women Satisfaction & No. & $\%$ \\
\hline Satisfaction with ginger intake & 40 & $80 \%$ \\
Satisfied & 6 & $12 \%$ \\
Dissatisfied & 4 & $8 \%$ \\
Uncertain & & \\
Preferred future use & 40 & $80 \%$ \\
Preferred & 2 & $4 \%$ \\
Not preferred & 8 & $16 \%$ \\
Uncertain & & \\
\hline
\end{tabular}

\section{Discussion}

Chemotherapy for cancer treatment is almost always followed by several side effects. However, nausea and vomiting are the most troublesome (Niccolai, Hicks, Oertel \& Francis 2004). Therefore, this study explored the effect of ginger tea intake to control nausea among 50 patients with gynecological malignancies receiving chemotherapy.

The socio-demographic characteristics of the study group, revealed that more than half of the study sample was more than 50 years and more than third between 35- 49 for control group; The finding of the study was in consistent with (Yadav, Sharma

, Patel, Rai ,and Ghoshal, 2017) they reported that The median age at BC diagnosis was 49 years and median follow-up of 14 years. In total, 25 cases of gynecological cancer were noted with an incidence of $0.9 \%$. We observed 9 ovarian and endometrium $(0.3 \%)$ as well as 7 uterine cervix $(0.25 \%)$ cancers.

Regarding educational level of the study group, less than one third can read and write, and more than one third had graduated from university. Concerning to marital status, more than two third of study and control group were married, and more than half of the study group were employed. In relation to types of cancer, more than quarter had cervical cancer, less than quarter had endometrial cancer, and less than half had breast cancer, as regards to grads of cancer. The finding of current study in consistent with Regarding the life-time cancer screening rates in 2009, according to cancer site, the 
second highest was breast cancer (78.1\%), and the third highest was cervical cancer $(76.1 \%)$, ovarian cancer is the second most common gynecological cancer in western women and the most common in the UK (Cancer Facts \& Figures 2010 in Korea).

Concerning Rhodes index score of nausea $\&$ vomiting experience at baseline and during intervention in both groups (study and control group), the current study declared that, before study intervention, there was no significant difference in frequency of experienced symptoms (nausea, vomiting and retching) between both study and control groups, while after intervention; the ginger tea group had significantly less symptoms of nausea, retching or vomiting than the control group. Moreover, regarding severity of nausea by experienced participant patients, significantly less patients in the intervention group experienced moderate or severe nausea after the first day than those in the control group. The results of the present study are consistent with those of Ryan et al, (2009) indicating that addition of ginger to standard antiemetic remedy causes additional decrease in chemotherapy-induced nausea but not vomiting during the first day of chemotherapy (Ryan et al, 2009).

From the researcher's view can only speculate that the mechanism by which ginger alleviates nausea is through a combination of anti-inflammatory and anti- spasmodic activities. Current antiemetic medications, such as 5-HT3, are receptor antagonists for specific neurotransmitters in the gastrointestinal tract. Likewise, ginger can bind 5-HT3 receptors to enhance antiemetic effects and can increase detoxification enzymes to counteract oxidative damage to tissues (Herrstedt \& Dombernowsky, 2007).

The finding of current study was in consistent with Panahi et al. (2012) conducted a randomized, open-label clinical trial that included 100 women with advanced breast cancer, who were assigned to standard chemotherapy protocol. Patients were randomized to receive ginger $(1.5 \mathrm{~g} / \mathrm{d}$ in 3 divided doses every 8 hours) plus standard antiemetic regimen (granisetron plus dexamethasone) or standard antiemetic regimen alone (control group). The duration of treatment with ginger was limited to 4 days from the initiation of chemotherapy. A significantly lower prevalence of nausea was observed in the ginger group during 6 to 24 hours $^{6}$ postchemotherapy. Despite this effect, no other significant additional benefits were observed with ginger in terms of prevalence or severity of nausea, vomiting or retching, in any of the assessed periods. Also Levine et al. (2008) reported that high- protein meals with ginger consumed twice daily were reported to reduce the delayed nausea of chemotherapy and decrease the use of antiemetic medications.

The finding of the study contradicts with Zick et al, (2009) who stated that addition of ginger does not decrease the frequency or severity of delayed CINV afar what is accomplished by standard treatment with granisetron plus dexamethasone. But, it must be noted that the findings of the present study may not be directly similar to some of the preceding reports because of differences in the source and amount of ginger, supplementation design, and chemotherapeutic treatment

Several mechanisms were postulated for the antiemetic action of ginger. Ashley (2012) stated that, as soon as ginger is taken, it starts to promote the secretion of saliva and then it promotes the secretion of various digestive juices or enzymes. This helps to neutralize the stomach acids. The phenols in the ginger help to relax the stomach muscles and to sedate the tissues 
of the stomach; this reduces the overactivity of the stomach, which in turn, reduces nausea and pain. At the same time, the phenols increase an intestinal movement which helps to move digested food and toxins through the digestive system. Grzanna et al. added that ginger root inhibits production of leukotrienes and prostaglandins, which are involved in pain and inflammation. (Grzanna et al 2005)

The current study was also assessed the total nausea and vomiting occurrence and distress in the intervention group (ginger tea) and control group, that there was no significant difference between ginger tea and control group before study intervention and during the first $6,12 \&$ 24 hours after chemotherapy. While there was a statistically significant association in intervention group (ginger tea) and control group on the second day, third day and fourth day post chemotherapy. The finding of current study was contradicted with Seena, (2016) who reported that, the level and occurrence of nausea and vomiting, majority of the participants $(80 \%)$ in the experimental group had no nausea and vomiting at $24 \mathrm{hrs}$ of chemotherapy while half of participant $(50 \%)$ in the control group had moderate to severe nausea and vomiting which indicates that the ginger complement is worth in decreasing chemotherapy induced nausea and vomiting. This might be due to the first dose of ginger were consumed about 30 minutes after the completion of chemotherapy. But in the current study the first dose of ginger tea starting 2 days before the chemotherapy session and 4 days after chemotherapy.

Regarding to women satisfaction towards ginger tea administration this study showed that, most women in the intervention group were satisfied with ginger tea intake to control their nausea after receiving chemotherapy and they preferred to take in future use. These findings reveal the satisfactory effect of ginger intake for prevention of

chemotherapy induced nausea and vomiting in our gynecologic oncology patients and breast cancer. Pradhan (2011) noted that ginger is one of the most highly consumed dietary substances in the world. It is an herb that can be used as a safe food component. (Pradhan SL, Pradhan PS 2011)

\section{Conclusion:}

On the light of the current study results, the researchers consider that ginger tea is an effective therapeutic choice in the avoidance of chemotherapy induced vomiting in both gynecological and breast cancer women. It is extensive availability, low cost, and unlimited acceptability profile, ginger may be an attractive choice, at least as a component in the combined antiemetic treatment, particularly in countries in which cost of care is a major problem.

\section{Recommendations;}

I. Prospective studies and longer periods of follow up are helpful to assess the efficacy of ginger supplementation on the prevalence of CINV symptoms in patients receiving multiple cycles of chemotherapy.

II. Further studies should be carried out on a large number of different types of cancer for evidence of the results and generalization.

\section{Acknowledgements}

The authors would like to thank of all the women in the study that participated in this study for their cooperation in collecting data.

\section{References}

1. Ali BH, Blunden G, Tanira MO , Nemmar A (2008). Some phytochemical, pharmacological and toxicological properties of ginger (Zingiber officinale Roscoe): a review of recent research. Food Chem Toxicol.; 46 (2):409- 20. 
2. Ashley S. How does ginger help with nausea. Available from: URL: http://www.ehow.com/howdoes_4588065_ginger-helpnausea.html. [cited 2017, Nov $5^{\text {th }}$ ] Bender, C.M, McDaniel, R.W, Murphy-Ende, K, Pickett, M, Rittenberg, C.N, Rogers, M.P,et al. (2012). Chemotherapy-induced nausea and vomiting. Clinical Journal of Oncology Nursing, 6, 94-102.

3. Baliga MS, Haniadka R, Pereira M, et al (2011). Update on the chemo preventive effects of ginger and its phytochemicals. Crit Rev Food Sci Nutr.; 51(6):499-523. [PubMed]

4. Black JM, Hawks JH (2009). Medical surgical nursing: Clinical management for positive outcomes. $8^{\text {th }}$ ed. Vol 1 . Saunders: Elsevier.

5. David M, Gershenson T, Pedro T, Ramirez. Overview of female reproductive system cancer. Cited 2017Oct 26. Available from: http://www.merckmanuals.com/home/ womens_health_issues/cancers_of_the _female_reproductive_system/overvie w_of_female_r eproductive_system_cancers.html.

6. Dundar EP, Ozmen D, Ozturk B, Haspolat G, Akyildiz F, Coban S (2006). The knowledge and attitudes of breast self-examination and mammography in a group of women in a rural area in western Turkey. BMC Cancer. 6:1-9. [PMC free article] [PubMed]

7. Edwards QT (2008), Palomares MR. Assessment of risk for breast cancer utilizing history and Quantitative models in primary care. J Nurse Pract.; 10:361-9.

8. Ernst E, Pittler MH (2000). Efficacy of ginger for nausea and vomiting: a systematic review of randomized clinical trials. Br J Anaesth 2000; 84:
367-371.

9. Fetzer SJ, Hand MC, Bouchard PA, Smith H, Jenkins MB (2004). Evaluation of the Rhodes Index of Nausea and Vomiting for ambulatory surgery patients. J Adv Nurs ; 47(1):74-80.

10. Giacosa A, Morazzoni P, Bombardelli E, Riva A, Bianchi Porro G, Rondanelli M (2015). Can nausea and vomiting be treated with ginger extract? Eur Rev Med Pharmacol Sci.; 19(7): 1291-6.

11. Grzanna R, Lindmark L, Frondoza CG (2005). Ginger-an herbal medicinal product with broad antiinflammatory actions. J Med Food; 8(2): 125-132.

12. Herrstedt J, Dombernowsky $P$ (2007). Anti-emetic therapy in cancer chemotherapy: current status. Basic Clin Pharmacol Toxicol.; 101:143-150. [PubMed: 17697032]

13. Hesketh PJ (2008). Chemotherapy induced nausea and vomiting. The new England Journal of Medicine; 358(23): 2482-2494.

14. Khalil NHK, Alaa El- Din S, Salem MA, Seif El-Din AA, Arafat WO (2010). The Effect of mbining Herbal Therapy with Conventional Chemotherapy on the incidence of Chemotherapy Side Effects in 2nd Stage Breast Cancer Patients. Journal of American Science; 6 (11): 784-801.

15. Kottschade L, Novotny P , Lyss A, Mazurczak M, Loprinzi C, and Barton D (2016) Chemotherapyinduced nausea and vomiting: incidence and characteristics of persistent symptoms and future directions NCCTG N08C3 (Alliance) Support Care Cancer. Jun; 24(6): 2661-2667.

16. Lete I, Allué J (2016). The Effectiveness of Ginger in the 
Prevention of Nausea and Vomiting during Pregnancy and Chemotherapy. Integr Med Insights.; 11: 11-

17. Published online 2016 Mar 31. doi: 10.4137/IMI.S36273

18. Levine M. E, Gillis M. G, Koch S. Y, Voss A. C, Stern R. M, Koch K. L. Protein and ginger for the treatment of chemotherapy-induced delayed nausea. J Altern Complement Med. 2008;14(5):54551.

19. Lewis S, Heitkemper, Dirksen (2004). Medical surgical nursing assessment and management of clinical problems. $6^{\text {th }}$ ed.Washington (USA): Mosby Publications.

20. Manusirivithaya S, Sripramote $M$, Tangjitgamol S, Sheanakul C, Leelahakorn S, Thavaramara $\mathrm{T}$, Tangcharoenpanich K (2004). Antiemetic effect of ginger in gynecologic oncology patients receiving cisplatin. Int $\mathbf{J}$ Gynecol Cancer; 14: 1063-1069.

21. Mustian KM, Darling TV, Morrow GR (2008).Chemotherapy-Induced Nausea and Vomiting. US oncology; 4(1):19-23.

22. Niccolai C, Hicks R, Oertel L and Francis J (2004). Curcuma: focus on high alert drug. Pharmacotherapy; 24(8):146-55.

23. Ojewole, J. A. (2006). Analgesic, anti-inflammatory and hypoglycemic effects of ethanol extract of Zingiber officinale (Roscoe) rhizomes (Zingiberaceae) in mice and rats. Phytother Res. 20: 764-772.

24. Osoba D, Zee B, Warr D, Kaizer L, Latreille J, Pater J (1996). Quality of life studies in chemotherapy-induced emesis. Oncology; 53 (suppl 1):9295.
25. Panahi Y, Saadat A, Sahebkar A, Hashemian F, Taghikhani M, Abolhasani E (2012). Effect of ginger on acute and delayed chemotherapy-induced nausea and vomiting: a pilot, randomized, openlabel clinical trial. Integr Cancer Ther; 11: 204- 211.

26. Payandeh M, Sadeghi M, Sadeghi E, Aeinfar M (2015). Clinicopathology figures and long-term effects of tamoxifen plus radiation on survival of women with invasive ductal carcinoma and triple negative breast cancer. Asian Pac J Cancer Prev, 16, 4863-7.

27. Pradhan SL, Pradhan PS (2011). Ayurvedic medicine and anesthesia. Indian J Anaesth; 55(4): 334-339.

28. Ryan JL, Heckler C, Dakhil SR, et al (2009). Ginger for chemotherapyrelated nausea in cancer patients: a URCC CCOP randomized, doubleblind, placebo- controlled clinical trial of 644 cancer patients. J Clin Oncol; 27(15, suppl pt 1):9511.

29. Seena ,Sahadeyan ( 2016) .Effect Of Ginger Supplement On Chemotherapy Induced Nausea And Vomiting Among Patients Receiving Cisplatin Attending Chemotherapy Unit Of Aims, Kochi .International Journal of Innovative Research and Advanced Studies (IJIRAS) Volume 3 Issue 10, September . ISSN: 23944404.

30. Sultani , M., Stringer, A. M., Bowen, J. M., and Gibson, R. J. (2012). Anti- Inflammatory Cytokines: Important Immunoregulatory Factors Contributing to ChemotherapyInduced Gastrointestinal Mucositis. Chemotherapy Research and Practice. 2012: 11.

31. Sun, C. C., Bodurka, D. C., Weaver, C. B., Rasu, R., Wolf, J. K., Bevers, 
M. W., Smith, J. A., Wharton, J. T., and Rubenstein, E. B. (2005).

Rankings and symptom assessments of side effects from chemotherapy: insights from experienced patients with ovarian cancer. Support Care Cancer. 13: 219-227.

32. Teunissen SC, Wesker W, Kruitwagen C, de Haes HC, Voest EE, de Graeff A (2007). Symptom prevalence in patients with incurable cancer: a systematic review. J Pain Symptom Manage; 34(1):94-104.
Yadav BS1, Sharma SC, Patel FD,

Rai B, Ghoshal S (2017)

.Gynecological Cancer as a Second Malignancy in Patients With Breast Cancer. Int J Gynecol Cancer. 2017 Jul; 27(6):1298-1304. doi:10.1097/IGC.000000000000099 3.

34. Zick, S. M., Turgeon, D. K., Vareed, S. K., Ruffin, M. T., Litzinger, A. J., Wright,B. D., Alrawi, S., Normolle, D. P., Djuric, Z., and Brenner, D. E. (2011). Phase II study of the effects of ginger root extract on eicosanoids in colon mucosa in people at normal risk for colorectal cancer. Cancer Prev Res (Phila). 4: 1929- 1937. 